\title{
Relationships between fish and otolith dimensions of Pomatomus saltatrix (Linnaeus, 1766) (Perciformes: Pomatomidae) in southeastern Brazil
}

\author{
Geysa M. de Souza ${ }^{1,3}$, Rafael de A. Tubino ${ }^{2}$, Cassiano Monteiro-Neto ${ }^{1,3}$ \\ and Marcus R. da Costa ${ }^{1,3}$
}

The bluefish, Pomatomus saltatrix (Linnaeus, 1766), was used as a species-specific model to study morphometric relationships between otolith size and relative growth variables. Length-weight relationships between Otolith (Length-OL, Height-OH, and Weight-OW) and fish measurements (Total Length-TL and Total Weight-TW) were determined for fishes captured monthly during the year 2015 off the southeastern coast of Brazil. The ANCOVA and Kruskal-Wallis analysis did not indicate significant differences in the relative growth constants between sexes and length frequency distributions $(p>0.05)$. The condition factor also did not present significant differences between sexes, and right and left otolith measurements $(p>$ 0.05). A total of 398 specimens were sampled: $\mathrm{TL}=43.6-67.0 \mathrm{~cm}, \mathrm{TW}=365-2400 \mathrm{~g}, \mathrm{OL}=9.65-15.25 \mathrm{~mm}, \mathrm{OH}=3.65-5.45$ $\mathrm{mm}$ and $\mathrm{OW}=0.03-0.11 \mathrm{~g}$. The LWR for grouped sexes was $\mathrm{TW}=0.050 \mathrm{TL}^{2.55}$ and otoliths $\mathrm{OW}=6.17 \mathrm{E}-05 \mathrm{OL}^{2.59}$. The best adjustments were TL vs OL $\left(\mathrm{r}^{2}=0.90\right)$; OL $v_{s} \mathrm{OW}\left(\mathrm{r}^{2}=0.90\right)$; TW $v_{s} \mathrm{OW}\left(\mathrm{r}^{2}=0.81\right)$; and TW $v_{s} \mathrm{OL}\left(\mathrm{r}^{2}=0.80\right)$. These results showed that such relationships are helpful tools for predicting the fish size and weight from otoliths, which may be used in food habits and paleontology studies, and other fisheries management applications.

Keywords: Bluefish, LWR, Otolith morphometrics, Sagitta otolith, Somatic growth.

A anchova, Pomatomus saltatrix (Linnaeus, 1766), foi usada como modelo espécie-específico de relações morfométricas de otólitos e variáveis de crescimento relativo. As relações peso-comprimento entre otólito (comprimento-CO, altura-AO e peso-PO) e tamanho do peixe (comprimento total-CT e peso total-PT) foram determinadas para indivíduos capturados mensalmente durante o ano de 2015 na costa sudeste do Brasil. As análises de ANCOVA e Kruskal-Wallis não indicaram diferenças significativas para as constantes de crescimento relativo entre os sexos e distribuições de frequência de comprimento $(p>$ $0,05)$. O fator de condição também não apresentou diferenças significativas entre os sexos, e medidas do otólito direito e esquerdo $(p>0,05)$. Um total de 398 espécimes foram amostrados: $\mathrm{CT}=43,6-67,0 \mathrm{~cm}$ e PT $=365-2400 \mathrm{~g}$. A RPC para peixes foi $\mathrm{PT}=0.050 \mathrm{CT}^{2,55} \mathrm{e}$ para os seus otólitos foi $\mathrm{PO}=6.17 \mathrm{E}-05 \mathrm{CO}^{2,59}, \mathrm{CO}=9.65-15.25 \mathrm{~mm}, \mathrm{AO}=3.65-5.45 \mathrm{~mm}$ and $\mathrm{PO}=$ $0.03-0.11$ g. Os melhores ajustes foram observados para CT vs CO $\left(\mathrm{r}^{2}=0,90\right)$; $\mathrm{CO} v s \mathrm{PO}\left(\mathrm{r}^{2}=0,90\right)$; PT vs PO $\left(\mathrm{r}^{2}=0,81\right) \mathrm{e}$ PT vs $\mathrm{CO}\left(\mathrm{r}^{2}=0,80\right)$. Os resultados mostraram que essas relações são ferramentas úteis na geração de estimativas de tamanho e peso dos peixes a partir dos otólitos, permitindo a sua aplicação em estudos em outras áreas, incluindo hábitos alimentares, paleontologia e manejo da pesca.

Palavras-chave: Anchova, Crescimento somático, Morfometria de otólitos, Otólitos sagitta, RPC.

\section{Introduction}

Fish otoliths are useful anatomical parts in several life history and ecological studies (Volpedo, Vaz dos Santos, 2015). Otoliths are metabolically inert, grow during the entire life cycle (Ferguson et al., 2011), and may be considered as permanent recorders of the environment on their Aragoni- te matrix. Animals are exposed to a combination of elements that are unique of their surroundings, with otoliths functioning as phenotypic markers (Panfili et al., 2002).

Otolith size and shape vary among species and individuals (Eroğlu, Şen, 2009), and may be used for morphometric analyzes. Aguilera et al. (2013) used otoliths for paleontological identification of fossil fishes, and Tuset et al. (2008)

${ }^{1}$ Laboratório de Biologia do Nécton e Ecologia Pesqueira, Departamento de Biologia Marinha, Universidade Federal Fluminense, Outeiro de São João Batista s/n, 24020-971 Niterói, RJ, Brazil. geysa.marinho@hotmail.com, Dhttps://orcid.org/0000-0003-4462-0255 (Corresponding author)

${ }^{2}$ Departamento de Biologia Animal, Universidade Federal Rural do Rio de Janeiro, Rodovia BR 465, Km 7, $23890-000$ Seropédica, RJ, Brazil. rattubino@gmail.com, Dhttps://orcid.org/0000-0002-3175-4724

${ }^{3}$ Programa de Pós-Graduação em Biologia Marinha, Departamento de Biologia Marinha, Universidade Federal Fluminense, Niterói, RJ, Brazil. (CMN) cmneto@id.uff.br, @ https://orcid.org/0000-0001-9342-8089,(MRC) marcusrc@id.uff.br, (Dhttps://orcid.org/0000-0002-0737-1184 
indicated their complementary use on stratigraphy, archaeology and zoogeography. Other applications include stock identification (Begg, Brown, 2000), and food habit studies (Tarkan et al., 2007). Additionally, otolith dimensions allow the back-calculationof fish size and biomass (Waessle et al., 2003), and weight to estimate age (Lepak et al., 2012). Also, otolith microchemistry composition provides chemical signalsthat may elucidate movements and migration patterns of fish stocks (Fraile et al., 2016).

Bluefish (Pomatomus saltatrix) is a marine pelagic migratory fish, found in continental shelf and estuarine waters of temperate and tropical regions (Juanes et al., 1996). The species is an active piscivorous fish (Haimovici, Krug, 1992), preyed by top predators such as sharks (Wood et al., 2009) and dolphins (Milmann et al., 2016). The bluefish is an important worldwide fishery resource captured by industrial, artisanal and recreational fisheries in the South Atlantic off the southeastern coast of Brazil (Haimovici, Krug, 1996; Lucena, O'Brien, 2005), in the North Atlantic along the coast of the United States (Buckel, Conover, 1997; Robillard et al., 2008), in eastern Australia (Zeller et al., 1996) and in the Mediterranean (Dhieb et al., 2005).

Several studies on the bluefish focused on age and growth (Krug, Haimovici, 1989; Robillard et al., 2009), reproduction (Haimovici, Krug, 1992; Robillard et al., 2008), diet (Haimovici, Krug, 1992) and fisheries (Haimovici, Krug, 1996; Lucena, O'Brien, 2005). Nevertheless, studies on the morphometric relationships of bluefish otoliths are few and geographically limited in the literature (Hare, Cowen, 1995;
Ceyhan, Akyol, 2006; Zengin et al., 2017; Bal et al., 2018). The aim of this paper was to provide information on the length-weight relationships (LWR) and condition factor (k) of bluefish, and the relationships between otolith dimensions and fish size, testing the hypothesis that such relations may provide useful predictive equations for estimating fish length and weight.

\section{Material and Methods}

Specimens of $P$. saltatrix were randomly collected from monthly commercial catches of gill net boats operating on the southeastern coast of Brazil $\left(23^{\circ} 00^{\prime} \mathrm{S}, 44^{\circ} 00^{\prime} \mathrm{W}\right.$ and $22^{\circ} 00^{\prime} \mathrm{S}, 41^{\circ} 00^{\prime} \mathrm{W}$ ), landed in Niterói (RJ) between January and December 2015 (Fig.1).

All individuals were measured to the nearest $0.1 \mathrm{~cm}$ for total length (TL) and the total weight of each fish was recorded to the nearest $0.01 \mathrm{~g}$. All TL values were distributed in size classes of $2 \mathrm{~cm}$ and the Kruskal-Wallis test was used to determine statistical differences in length frequency distributions between sexes. Sex was determined by macroscopic examination of the gonads $(219+174 \hat{\circ}$ and 5 unidentified) using a standard classification (Brown-Peterson et al., 2011). The pairs of sagittal otoliths were removed cleaned and stored in small, labeled envelopes. Otolith length (OL) was measured by a digital caliper rule $(0.01 \mathrm{~mm})$ and otolith weight $(\mathrm{OW})$ with an electronic precision balance (Bioprecisa JA3003, $0.0001 \mathrm{~g})$. OL was considered as the greatest distance between anterior and posterior edge, and $\mathrm{OH}$ as the

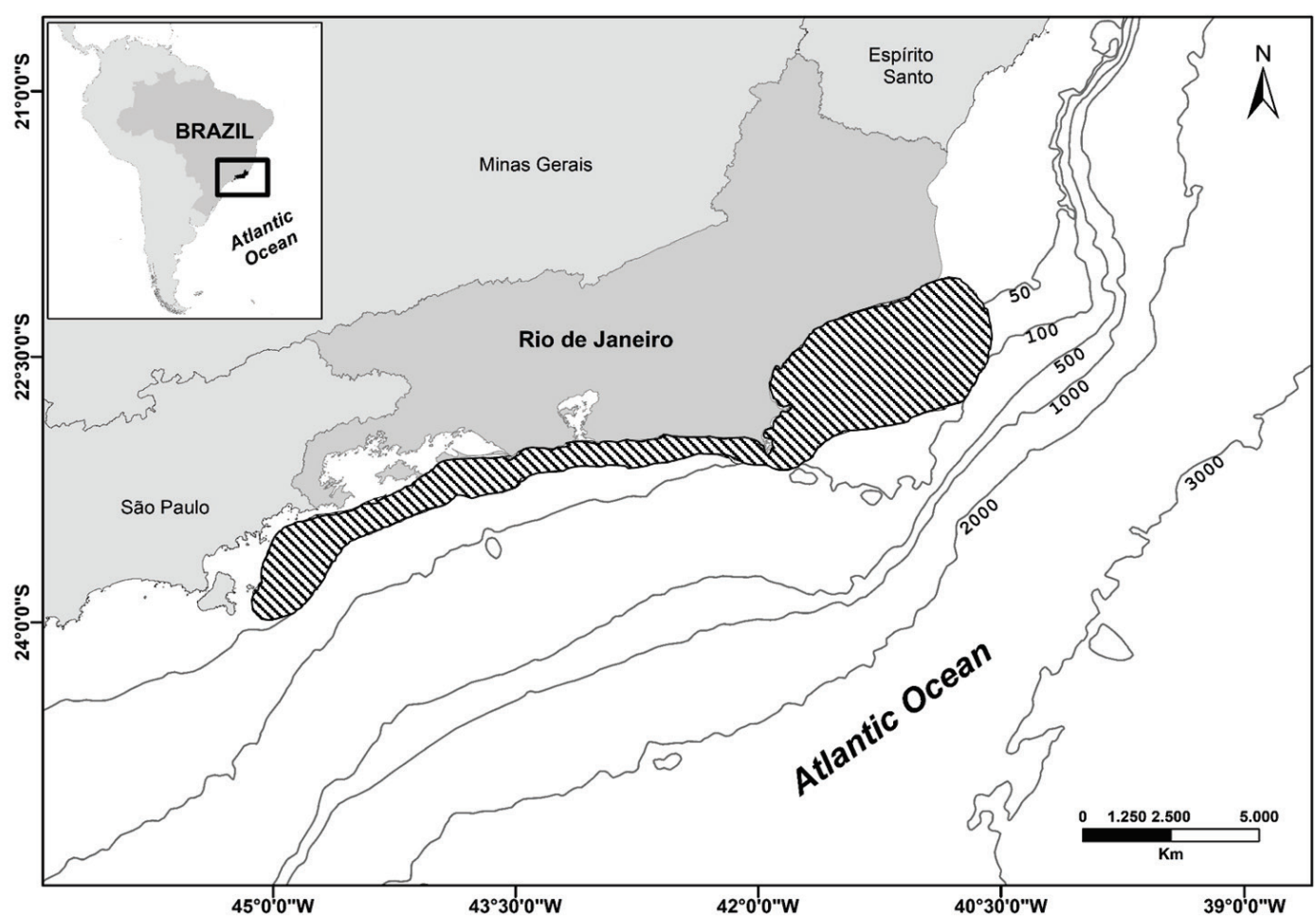

Fig. 1. Map of sampling area, hatched area identifies where catches of Pomatomus saltatrix occurred, off the Brazilian coast in the Southeastern Atlantic Ocean. 
greatest distance from dorsal ventral edge (Fig. 2). A t-test was used to determine differences between left and right otoliths.

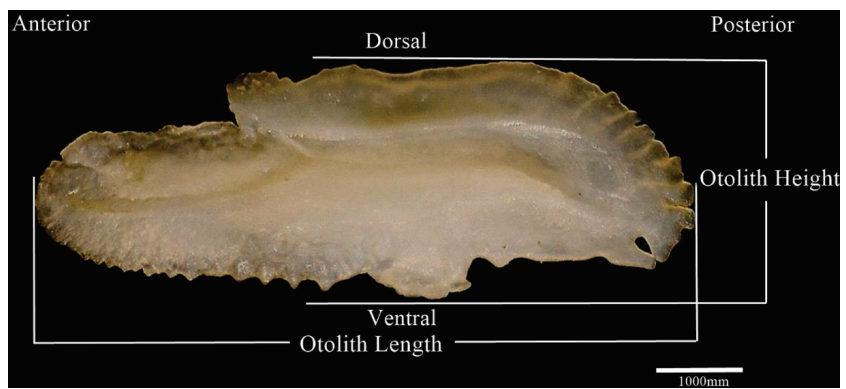

Fig. 2. Left sagitta otolith of Pomatomus saltatrix, with indicated measurements $(\mathrm{TL}=57.9 \mathrm{~cm}, \mathrm{TW}=1817.0 \mathrm{~g})$.

The LWR is expressed by the equation: TW $=a \times \mathrm{TL}^{b}$, where TW is the body weight, TL is the total length, $a$ and $b$ are regression parameters. Parameters $a$ and $b$ were estimated by the converted logarithmic expression: $\log$ TW $=$ $\log a+b \log \mathrm{TL}$, where $a$ is the intercept of the regression curve (coefficient related to body form) and $b$ the regression coefficient (exponent indicating isometric growth) (Froese, 2006). Additionally, the $95 \%$ confidence limits (CL) of $a$ and $b$ were estimated. Outliers observed in the $\log -\log$ curves of all species were excluded from the regression. The difference between sexes for LWR was tested using analysis of covariance (ANCOVA). The hypothesis of isometric growth $(b=$ 3) (Zar, 2010) was tested with the Student's t-test. We also estimated the condition factor, a quantitative parameter of the well-being of the fish, by the following expression: $\mathrm{k}=\mathrm{TW}$ / $\mathrm{TL}^{b}$, where $\mathrm{k}$ represents the condition factor and $b$ the alometry coefficient, which is related with the form the individuals grow, and calculated from the length-weight relationship (Le-Cren, 1951). The analysis of variance (ANOVA) was applied to verify significant differences between sexes for the $\mathrm{k}$ values. The relationship between the otolith size (length-OL, height-OH, weight-OW) and fish size (total length-TL, total weight-TW) were determined using a power regression model between various measurements (Zar, 1984). The agreement between the models and the data was verified with the coefficient of determination $\left(\mathrm{r}^{2}\right)$. Statistical analyses were performed using Statistica ${ }^{\mathrm{TM}}$ (StatSoft Inc., 2007) and regression models compiled under Excel software (version 2007) for determining the relationships between fish size and otolith size. $P<0.05$ was considered as the significance level.

\section{Results}

A total of 398 pairs of otoliths were collected and analyzed from specimens ranging between $43.6 \mathrm{~cm}$ and $67.0 \mathrm{~cm} \mathrm{TL}$ (mean $\pm \mathrm{SD}=51.8 \pm 5.30 \mathrm{~cm}$ ), and $365.0 \mathrm{~g}$ to $2400.0 \mathrm{~g} \mathrm{TW}$ (mean $\pm \mathrm{SD}=1182.4 \pm 352.3 \mathrm{~g}$ ). Within the collected samples only five specimens were not sexually identified ( $\mathrm{TL}=45.5$ to
$53.0 \mathrm{~cm})$, the females $(\mathrm{N}=219)$ ranging between $44.1 \mathrm{~cm}$ to $67.0 \mathrm{~cm}$ TL slightly prevailed over males $(\mathrm{N}=174,43.6 \mathrm{~cm}$ to $66.1 \mathrm{~cm} \mathrm{TL}$ ), and no significant difference was observed between size classes (Kruskal-Wallis, $\mathrm{H}=13.52, p=0.332$ ). Regarding the size structure, approximately $50 \%$ of the specimens analyzed occurred between the classes of 44.0 and 48.0 $\mathrm{cm}$ TL (Fig. 3a), indicating that captured individuals were above the length of first sexual maturity and near the length limit where all individuals are sexually mature $\left(\mathrm{L}_{50}=40.0 \mathrm{~cm}\right.$; $\mathrm{L}_{100}=45.0 \mathrm{~cm}$; Haimovici, Krug, 1992).
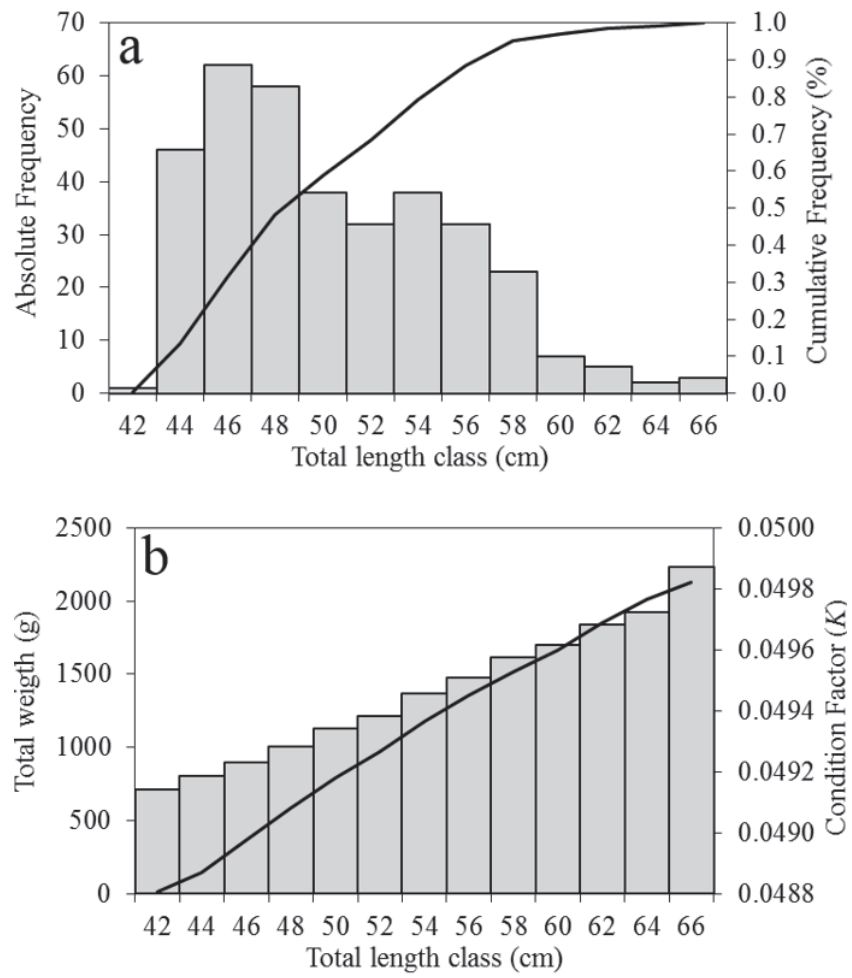

Fig. 3. Absolute and cumulative frequency of individuals by length class $(\mathrm{cm})(\mathrm{a})$ and total weight of individuals by length class and condition factor (k) (b) of Pomatomus saltatrix, obtained from commercial catches off the Brazilian coast in the Southeastern Atlantic Ocean.

The covariance analysis (ANCOVA) applied to the parameters of the length-weight relationship for sexes was not significant $(\mathrm{F}=2.791, \mathrm{df}=1, p=0.096)$. The LWR equation for all individuals sampled was TW $=0.050 \mathrm{TL}^{2.55}$ with the coefficient of determination $r^{2}=0.94$ and " $b$ " value equals to $2.550(\mathrm{CI} \pm 0.64)$ indicate that this relationship is robust, in spite of a narrow range in sizes evaluated. The condition factor ranging from 0.0488 to 0.0498 also did not present significant differences between the sexes $(p=0.166)$. The mean $\mathrm{k}$ values per length class followed the biomass gain, regardless of the coefficient $b$ estimated, which was lower than 3 (isometry) $(p<0.05)$, indicating that in this phase of relative growth, the species presents a larger increase in length in relation to weight (Fig. 3b). 
Relationships between fish size and otolith size were described using a power regression model between measures and were statistically significant $(p<0.05)$. The coefficients of determination showed values ranging from 0.66 to 0.89 (Tab. 1). Otolith length (OL) ranged from 9.65 to $15.25 \mathrm{~mm}$ $($ mean $\pm \mathrm{SD}=12.60 \pm 0.95)$, height $(\mathrm{OH})$ from $3.65 \mathrm{~mm}$ to $5.45 \mathrm{~mm}$ (mean $\pm \mathrm{SD}=4.29 \pm 0.31)$, and weight $(\mathrm{OW})$ from $0.03 \mathrm{~g}$ to $0.11 \mathrm{~g}($ mean $\pm \mathrm{SD}=0.05 \pm 0.01)$ for all samples.

Tab. 1. Power regression relationships between fish size $v s$ otolith size and measures of otoliths of Pomatomus saltatrix. Number of specimens $(n)$ and coefficients of determination $\left(\mathrm{r}^{2}\right)$ and parameters of power equations. $\mathrm{r}^{2}$ : Correlation Coefficient; ' $a$ ' and ' $b$ ': regression parameters; CI: $95 \%$ confidence interval; OL: otolith length; $\mathrm{OH}$ : otolith height; OW: otolith weight; TL: total length; TW: total weight.

\begin{tabular}{ccccccc}
\hline $\begin{array}{c}\text { Relationship } \\
\text { between }\end{array}$ & $n$ & $a$ & $\pm \mathrm{CI}(a)$ & $b$ & $\pm \mathrm{CI}(b)$ & $\mathrm{r}^{2}$ \\
\hline TL vs OL & 258 & 1.2294 & 0.1750 & 0.5899 & 0.2860 & 0.90 \\
TL vs OH & 288 & 0.6828 & 0.2280 & 0.4667 & 0.0400 & 0.65 \\
TL vs OW & 325 & $6.49 \mathrm{E}-05$ & 0.00003 & 1.6510 & 0.1158 & 0.71 \\
TW vs OL & 258 & 2.3702 & 0.2427 & 0.2370 & 0.0145 & 0.80 \\
TW vs OH & 325 & 1.3187 & 0.1596 & 0.1664 & 0.0172 & 0.53 \\
TW vs OW & 226 & 0.0004 & 0.0001 & 0.6795 & 0.0440 & 0.81 \\
OL vs OH & 259 & 3.464 & 0.3887 & 0.8880 & 0.0710 & 0.67 \\
OL vs OW & 222 & $6.17 \mathrm{E}-05$ & 0.00002 & 2.5996 & 0.1174 & 0.90 \\
OH vs OW & 281 & 11.2370 & 0.8932 & 0.3088 & 0.0250 & 0.68 \\
\hline
\end{tabular}

The shape of the sagittae otolith of adults is rectangular to lanceolate with the anterior region rounded-lanceolate and the posterior region oblique or oblique-rounded. The dorsal border is lobed to sinuous and ventral border is sinuous to irregular. The profile is concave and flattened. The Sulcus acusticus shows a horizontally oriented medial position with ostial funnel of tubular form moderately curved.The best linear regressions between the sizes of fishes and otoliths were: TL vs OL, $\mathrm{r}^{2}=0.90$; OL vs OW, $\mathrm{r}^{2}=0.90$; TW vs $\mathrm{OW}, \mathrm{r}^{2}=0.81$;W vs OL, $\mathrm{r}^{2}=0.80$. The relationship OL $v s$ OW showed a negative allometric growth (t-test, $p<0.05$ ), reinforcing the pattern of a predominant length growth upon weight, resulting in the elongated shape (Fig. 4).

\section{Discussion}

Our results showed that the relative growth and the relationships between fish size and otolith size might be used as valuable tools for fisheries management and research. Such applications require the use of morphometric variables from data collected in the field to be transformed into appropriate indices. First, the most commonly used in any analysis of fishery data is the length-weight relationship for estimating the biomass from length. It also provides information on the condition of fish, which is frequently used for comparisons at different scales (Moutopoulos, Stergiou, 2002). Second, the shape and the relationship between the length of a fish and its otolith measures have provided important information to identify species, and to estimate fish length from otoliths. In fact, Aguilera et al. (2013) produced length frequency distributions of fishes from otoliths recovered in archaeological sites.

The Comparisons of bluefish LWR in this work and those previously reported in the literature showed variations in the form the species grows (Frota et al., 2004; Ak et al., 2009; Bok, et al., 2011). Such comparisons indicated that the value of the slope $b$ varies between 2.509 (negative allometric growth) and 3.330 (positive allometric growth) including the results of this study.

Cumplido et al. (2018), working within the same region in the southeastern coast of Brazil, observed $b$ values similar to those reported here, despite the fact that their size range included smaller fishes. This negative allometric growth pattern $(b=2.55)$ was slightly smaller than that observed for the southern coast of Brazil ( $b=3.05$, positive allometric growth) (Bernardes, Rossi-Wongtschowski, 2000; Haimovici, Velasco, 2000), slightly higher than the Mediterranean $(b=$ 2.52) (Bok et al., 2011), and the middle Brazilian coast ( $b=$ 2.50, negative allometric growth) (Frota et al., 2004). These observed differences in the LWR estimated parameters are highly affected by food availability, reproductive periods, migratory activities and abiotic factors (Rossi-Wongtschowski, 1977; King, 1995). Furthermore, sampling associated variables, including sample size and the length range of individuals also influence the LWR parameters.

The variations of the condition factor $(k)$ for the strata of TL evaluated are related to the fluctuations of the sexual cycle, for both genders. Indeed, the higher values of $\mathrm{k}$ increased proportionally with size and sexually maturity. Many authors suggest that these variations in $\mathrm{k}$ reflect specific environmental conditions such as temperature and salinity of seawater, food availability, and inherent species conditions including the age of the fish, sex, amount of fat reserve, degree of muscular development and changes in maturity stages (Barnham, Baxter, 1998; Froese et al., 2006; Muchlisin et al., 2017).

In our study, no noticeable intraspecific differences occurred among sexes and otolith pairs for the evaluated length strata of bluefish, which permitted the presentation of the grouped sexes model. Similar findings were obtained by Zengin et al. (2017) and Bal et al. (2018). Nevertheless, Hare, Cowen (1995) reported that these differences may occur due to the variability in individual growth rates. According to Froese (2006) the sample size, the size range of specimens, differences across populations, gonadal maturity, and preservation techniques could explain intraspecific differences and in the allometric coefficients. This type of relationship between morphometric and morphological characteristics between parts of an organism has been widely applied for several species, such as Psenopsis cyanea (Alcock, 1890), Pterygotrigla hemisticta (Temminck, Schlegel, 1843), Bembrops caudimacula Steindachner, 1876 (Aneesh Kumar, 2017) and Otolithes ruber (Bloch, Schneider, 1801) 

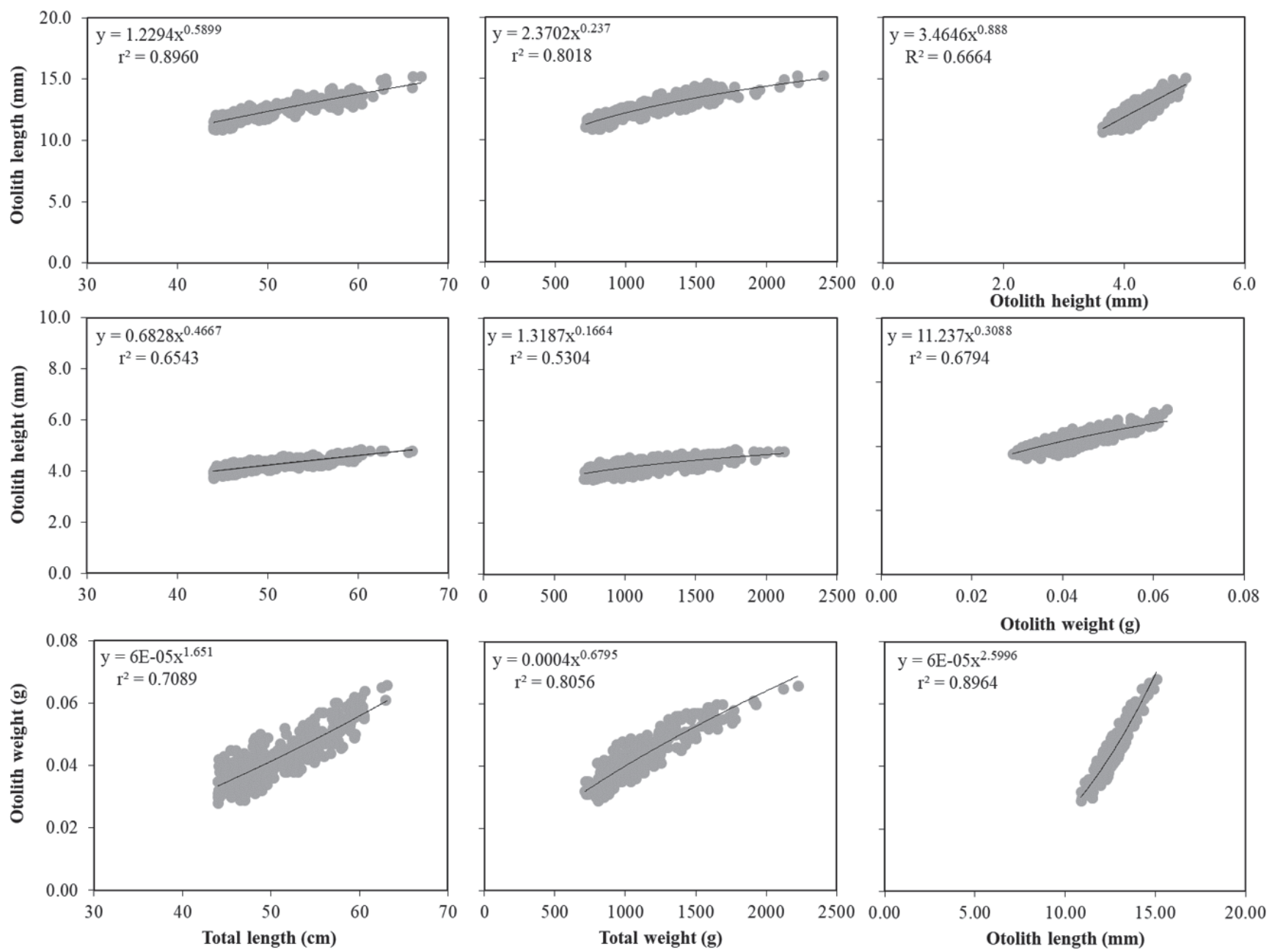

Fig. 4. Relationship between fish size and otolith size and measures of otoliths of Pomatomus saltatrix captured off the Brazilian coast in the southeastern Atlantic Ocean.

(Rahnama et al., 2017), demonstrating the importance of this tools to evaluate populations or stocks.

Otoliths have long been recognized as one of the most useful fish anatomic structures because of their accretionary growth and species-specific shape, often used to determine the age of fishes. Additionally, otolith microchemistry has been used in recent years to unveil aspects of fish species life cycle (Fraile et al., 2016). However, these analyzes are costly and dependent on sensible equipment. Thus, a simplest and most accessible way to obtain information about a population and/or stock is to proceed with otolith length and weight measurements, besides LWR, for comparative studies. Otoliths are also used for identification/discrimination of populations (Stransky et al., 2008), ecomorphological studies (Volpedo, Vaz dos Santos, 2015) and the determination of fish prey identity in feeding studies (Tarkan et al., 2007). Moreover, in some fish species, age can be determined by otolith weight due to high correlation (Cardinale, Arrhenius, 2004).

Most studies providing relationships between otolith morphology and the total length of bluefish are restricted to the Mediterranean and Black Sea (Ceyhan, Akyol, 2006;
Cengiz et al., 2012; Zengin et al., 2017; Bal et al., 2018). Our results for the southwestern Atlantic showed highest correlations between TL vs OL $\left(\mathrm{r}^{2}=0.89\right)$, OL vs OW $\left(\mathrm{r}^{2}\right.$ $=0.89)$, TW vs OW $\left(\mathrm{r}^{2}=0.80\right)$ and TW vs OL $\left(\mathrm{r}^{2}=0.80\right)$, indicating that these models may be used as functional tools for estimating fish size from otolith dimensions. Bal et al. (2018) observed that the length and height of the otoliths were the best predictors for the TL of bluefish from commercial catches in the Turkish Sea. Other authors registered that otolith length is a good predictor of fish size with regression coefficient higher than our study $\left(\mathrm{r}^{2}=0.93\right.$ - Ceyhan, Akyol, 2006), lower $\left(r^{2}=0.61\right.$ - Zengin et al., 2017) and similar $\left(r^{2}=0.88\right.$ - Bal et al., 2018; $\mathrm{r}^{2}=0.89$ - Cengiz et al., 2012). These high $\mathrm{r}^{2}$ values indicating the good applicability of this tool, i.e., a high level of precision in measurement of the data should imply a high accuracy in coefficient of determination and the possibility to analyze samples with a large number of individuals, reducing bias derived from smaller sample sizes.

The divergence found in the relationship of fish size and otoliths of bluefish obtained in the present study, compared 
with other studies, is justified by differences in the size range of specimens analyzed. Moreover, data from the literature corresponds to the populations of eastern Atlantic Ocean bluefish, the Mediterranean and the Black Sea. Moreover, all populations presented a positive relationship between total fish length and otolith length, suggesting that this is a strong characteristic of the sagittae otoliths of this species, corroborating with our study.

Due to the limited research and data availability on $P$. saltatrix in the southeastern coast of Brazil, comparisons between fish size $v s$ otolith size with local previous research were not possible. However, this research is a new contribution in the studies of otolith dimensions as a predictor of size for this fish species. The equations here derived, showing high correlations, may be used as estimators of the selected variables in population dynamic and stock assessment studies of the species. Thus, the morphometric relationships are shown to be useful tools for fisheries management.

\section{Acknowledgements}

We thank the trainees and staff from ECOPESCA-UFF and FIPERJ for their efforts in this cooperative project. This research supported by FAPERJ (Grant \# E-26/112.613/2012) and CNPq (Grant \# 406249/2012-1). G. M. de Souza holds a Master's degree scholarship from CAPES, C. Monteiro-Neto a Research Productivity Fellowship from CNPq (Grant \# 305292/2016-1), and R. A. Tubino a post-doctoral fellowship PNPD-CAPES.

\section{References}

Aguilera OA, Moraes-Santos H, Costa S, Ohe F, Jaramillo C, Nogueira A. Ariid sea catfishes from the coeval Pirabas (Northeastern Brazil), Cantaure, Castillo (Northwestern Venezuela), and Castilletes (North Colombia) formations (early Miocene), with description of three new species. Swiss J Palaeontol. 2013; 132(1):45-68. http://dx.doi.org/10.1007/ s13358-013-0052-4

Ak O, Kutlu S, Aydın İ. Length-weight relationship for 16 fish species from the Eastern Black Sea. Turk J Fish Aquat Sci. 2009; 9:125-26.

Aneesh Kumar KV, Deepa KP, Hashim M, Vasu C, Sudhakar M. Relationships between fish size and otolith size of four bathy demersal fish species from the south eastern Arabian Sea, India. J Appl Ichthyol. 2017; 33(1):102-07. http://dx.doi.org/10.1111/ jai. 13250

Bal H, Yanık T, Türker D. Relationships between total length and otolith size of bluefish Pomatomus saltatrix (Linnaeus, 1766) in the Marmara Sea of Turkey. Nat Eng Sci. 2018; 3(1):38-44. https://doi.org/10.28978/nesciences.379319

Barnham C, Baxter. Condition factor, K, for salmonid fish. Fisheries notes. Victoria Department of Primary Industries. Australia: Melbourne; 1998.

Begg GA, Brown RW. Stock identification of haddock Melanogrammus aeglefinus on Georges Bank based on otolith shape analysis. Trans Am Fish Soc. 2000; 129(4):935-45. http://dx.doi.org/10.1577/1548 8659(2000)129<0935:SIOHM $\mathrm{A}>2.3 . \mathrm{CO} ; 2$
Bernardes RA, Wongtschowski CLDBR. Length-weight relationship of small pelagic fish species of the southeast and South Brazilian Exclusive Economic Zone. Naga, the ICLARM Quarterly. 2000; 23(4):30-32.

Bok TD, Göktürk D, Kahraman AE, Alicli TZ, Acun T. Lengthweight relationships of 34 fish species from the Sea of Marmara, Turkey. J Anim Vet Adv. 2011; 10(23):3037-42.

Brown-Peterson NJ, Wyanski DM, Saborido-Rey F, Macewicz BJ, Lowerre-Barbieri SK. A standardized terminology for describing reproductive development in fishes. Mar Coast Fish. 2011; 3(1):52-70. https://doi.org/10.1080/19425120.2011.555724

Buckel JA, Conover DO. Movements, feed in periods, and daily ration of piscivorous young-of-the-year bluefish, Pomatomus saltatrix, in the Hudson River estuary. Fish Bull 1997; 95:665679.

Cardinale M, Arrhenius F. Using otolith weight to estimate the age of haddock (Melanogrammus aeglefinus): a tree model application. J Appl Ichthyol. 2004; 20(6):470-75. http://dx.doi. org/10.1111/j.1439-0426.2004.00576.x

Ceyhan T, Akyol O. Marmara Denizi'ndeki Lüfer balığının Pomatomus saltatrix (Linnaeus, 1766) büyüme ve üreme özellikler. EÜ Su Ürünleri Dergisi. 2006; 23(1-3):369-72.

Cumplido R, Netto EBF, Rodrigues MT, de Melo Junior UG, da Costa PAS. A review and the length-weight relationship of bluefish, Pomatomus saltatrix (Linnaeus, 1766), Pisces: Pomatomidae, at the Marine Extractive Reserve (RESEX-Mar) of Arraial do Cabo, Rio de Janeiro State, Brazil. Open Access Library Journal. 2018; 5(8):1. https://doi.org/10.4236/oalib.1104770

Dhieb K, Ghorbel M, Bouain A. Age etcroissance du serre Pomatomus saltatrix (Pomatomidae) du golfe de Gabès (Tunisie). Mésogée. 2005; 61:43-50.

Eroğlu M, Şen D. Otolith size-total length relationship in spiny eel, Mastacembelus mastacembelus (Banks \& Solander, 1794) inhabiting in Karakaya Dam Lake (Malatya, Turkey). Journal of Fisheriessciences.com. 2009; 3(4):342-51. http://dx.doi. org/10.3153/jfscom.2009039

Ferguson GJ, Ward TM, Gillanders BM. Otolith shape and elemental composition: Complementary tools for stock discrimination of mulloway (Argyrosomus japonicus) in southern Australia Fish Res. 2011; 110(1):75-83. http://dx.doi.org/10.1016/j. fishres.2011.03.014

Fraile I, Arrizabalaga H, Santiago J, Goñi N, Arregi I, Madinabeitia S, Wells D, Rooker JR. Otolith chemistry as an indicator of movements of albacore (Thunnus alalunga) in the North Atlantic Ocean. Mar Freshw Res. 2016; 67(7):1002-13. http:// dx.doi.org/10.1071/MF15097

Froese R. Cube law, condition factor and weight-length relationships: History, meta-analysis and recommendations. J Appl Ichthyol. 2006; 22(4):241-53. http://dx.doi.org/10.1111/ j.1439-0426.2006.00805.x

Frota LO, Costa PAS, Braga AC. Length-weight relationships of marine fishes from the central Brazilian coast. Naga, World Fish Center Quarterly. 2004; 27:20-26.

Haimovici M, Krug LC. Alimentação e reprodução da enchova Pomatomus saltatrix no litoral Sul do Brasil. Braz J Biol. 1992; 52(3):503-13.

Haimovici M, Krug LC. Life history and fishery of the enchova, Pomatomus saltatrix, in southern Brazil. Mar Freshw Res. 1996; 47(2):357-63. http://dx.doi.org/10.1071/MF9960357

Haimovici M, Velasco G. Length-weight relationships of marine fishes from southern Brazil. Naga ICLARM Quarterly. 2000; 23(1):19-23. 
Hare JA, Cowen RK. Effect of age, growth rate, and otogeny on the otolith size-fish size relationships in bluefish Pomatomus saltatrix, and the implications for the back-calculation of size in early life history stages. Can J Fish Aquat Sci. 1995; 52(9):1909-22. http://dx.doi.org/10.1139/f95-783

Juanes F, Hare JA, Miskiewicz AG. Comparing early life history strategies of Pomatomus saltatrix: a global approach. Mar Freshw Res. 1996; 47(2):365-79. http://dx.doi.org/10.1071/ MF9960365

King M. Fisheries biology, assessment and management. Fishing new books. England: Osney Mead, Oxford; 1995.

Krug LC, Haimovici M. Idade e crescimento da enchova Pomatomus saltatrix do Sul do Brasil. Atlântica. 1989; 11(1):47-61.

Le Cren ED. The length-weight relationship and seasonal cycle in gonad weight and condition in the perch (Perca fluviatilis). J Anim Ecol. 1951; 20 (2):201-19. https://doi.org/10.2307/1540

Lepak JM, Cathcart CN, Hooten MB. Otolith mass as a predictor of age in kokanee salmon (Oncorhynchus nerka) from four Colorado reservoirs. Can J Fish Aquat Sci. 2012; 69(10):156975. http://dx.doi.org/10.1139/f2012-081

Lucena FM, O'Brien CM. The consequences of different scenarios in the management of the gillnet and purse-seine fisheries targeting Pomatomus saltatrix and Cynoscion guatucupa in southern Brazil: a bio-economic approach. ICES J Mar Sci. 2005; 62:201-13.https://doi.org/10.1016/j.icesjms.2004.11.011

Milmann L, Danilewicz D, Machado R, Santos RAD, Ott PH. Feeding ecology of the common bottlenose dolphin, Tursiops truncatus, in southern Brazil: analyzing its prey and the potential overlap with fisheries. Braz J Oceanogr. 2016; 64(4):415-22. http://dx.doi.org/10.1590/s1679-87592016116406404

Moutopoulos DK, Stergiou KI. Length-weight and length-length relationships of fish species from the Aegean Sea (Greece). J Appl Ichthyol. 2002; 18(3):200-03. https://doi.org/10.1046/ j.1439-0426.2002.00281.x

Muchlisin ZA, Fransiska V, Muhammadar AA, Fauzi M, Batubara AS. Length-weight relationships and condition factors of the three dominant species of marine fishes caught by traditional beach trawl in Ulelhee Bay, Banda Aceh City, Indonesia. Ribarstvo. 2017; 75(3):104-12.

Panfili J, Pontual H (De), Troadec H, Wrigh PJ. Manual of fish sclerochronology. Brest, France: Ifremer-IRD coediction; 2002.

Rahnama B, Kamrani E, Radfar F, Yadollahvand R, Parsa M. The relationship between otolith size and estimated age of tigertooth croaker (Otolithes ruber Bloch and Schneider, 1801) in Oman Sea, Iran. J Appl Ichthyol. 2017; 33(5):978-82. http:// dx.doi.org/10.1111/jai.13404

Robillard E, Reiss CS, Jones CM. Reproductive biology of bluefish (Pomatomus saltatrix) along the East Coast of the United States. Fish Res. 2008; 90(1):198-208. http://dx.doi. org/10.1016/j.fishres.2007.10.020
Robillard E, Reiss CS, Jones CM. Age-validation and growth of bluefish (Pomatomus saltatrix) along the East Coast of the United States. Fish Res. 2009; 95(1):65-75. https://doi. org/10.1016/j.fishres.2008.07.01

Rossi-Wongtschowski CLDB. Estudo das variações da relação peso total/comprimento total em função do ciclo reprodutivo e comportamento, de Sardinella brasiliensis (Steidachner, 1879) da costa do Brasil. Bolm Inst Oceanogr. 1977; 26:131-80.

StatSoft, Inc. (2007). STATISTICA(data analysis software system), version 8.0. Retrieved from www.statsoft.com

Stransky C, Murta AG, Schlickeisen J, Zimmermann C. Otolith shape analysis as a tool for stock separation of horse mackerel (Trachurus trachurus) in the Northeast Atlantic and Mediterranean. Fish Res. 2008; 89(2):159-66. http://dx.doi. org/10.1016/j.fishres.2007.09.017

Tarkan AS, Gaygusuz CG, Gaygusuz O, Acipinar H. Use of bone and otolith measures for size-estimation of fish in predatorprey studies. Folia Zool. 2007; 56(3):328-36.

Tuset VM, Lombarte A, Assis CA. Otolith atlas for the western Mediterranean, north and central eastern Atlantic. Sci Mar. 2008; 72(S1):7-198. http://dx.doi.org/10.3989/scimar.2008.72s17

Volpedo AV, Vaz-dos-Santos AM. Métodos de estúdios com otolitos: principios y aplicaciones/Métodos de estudos com otólitos: princípios e aplicações. Edición bilingue, Argentina: Ciudad Autónoma de Buenos Aires; 2015.

Waessle JA, Lasta CA, Bavero M. Otolith morphology and body size relationships for juvenile Sciaenidae in the Río de la Plata estuary (35-36º S). Sci Mar. 2003; 67(2):233-40. http://dx.doi. org/10.3989/scimar.2003.67n2233

Wood AD, Wetherbee BM, Juanes F, Kohler NE, Wilga C. Recalculated diet and daily ration of the shortfin mako (Isurus oxyrinchus), with a focus on quantifying predation on bluefish (Pomatomus saltatrix) in the northwest Atlantic Ocean. Fish Bull. 2009; 107(1):76-88.

Zar JH. Biostatistical Analysis. Eaglewood Cliffs, NJ: Prentice Hall; 1984.

Zar JH. Biostatistical analysis. 5th ed. Upper Saddle River (NJ): Prentice Hall; 2010.

Zeller BM, Pollock BR, Williams LE. Aspects of the life history and management of tailor (Pomatomus saltatrix) in Queensland. Mar Freshw Res. 1996; 47(2):323-32. http:// dx.doi.org/10.1071/MF9960323

Zengin M, Saygin S, Polat N. Relationships between otolith size and total length of bluefish, Pomatomus saltatrix (Linnaeus, 1766) in Black Sea (Turkey). North-West J Zool. 2017; 13(1):169-71.

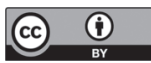

Submitted Mar 14, 2018 Accepted February 11, 2019 by Alexandre Hilsdorf 
